\title{
Plaučių vèžio spindulinio gydymo galimybės ir perspektyva
}

\author{
Laimonas Jaruševičius, Elona Juozaitytė \\ LSMU MA Onkologijos institutas
}

Reikšminiai žodžiai: plaučių věžio spindulinis gydymas, IMRT, IGRT, SBRT.

Santrauka. Efektyvus ir sèkmingas lokalus plaučiu věžio spindulinis gydymas gali turèti įtakos ligonių gyvenimo trukmei. Taikant šiuolaikines spindulinio gydymo technologijas pavyksta optimizuoti jonizuojančiosios spinduliuotės dozę navikui tausojant aplinkinius audinius. Standartinis spindulinis gydymas turi trūkumų: apšvitinamas didesnis sveikų audinių tūris, o tai gali sukelti spindulines komplikacijas, galimybė saugiai didinti jonizuojančiosios spinduliuotės dozę yra ribota, taigi sunkiau vykdyti lokalią naviko kontrolę. Tiksliau vizualizuojant naviką spindulinio gydymo metu, galima siekti mažesnès sveikų audinių apšvitos bei didesnio jonizuojančiosios spinduliuotės poveikio navikui. Taikant didelių dozių spindulinį gydymą labai svarbu jivertinti ir kompensuoti pacientų pozicionavimo paklaidas, kvėpavimo judesių sąlygotą organų judejjimą. Naujos spindulinio gydymo technologijos atveria galimybes labai tiksliai apšvitinti naviką. Šioje apžvalgoje norima trumpai supažindinti su šiuolaikinio spindulinio gydymo galimybėmis ir patirtimi gydant plaučiu věži.

Nepakankamai efektyvus ir saugus lokalus spindulinis gydymas gali turèti ịtakos plaučiu vėžiu sergančiu ligoniụ išgyvenamumui. A. Auperin ir bendr. atlikta metaanalizè patvirtino, kad sèkminga lokali plaučių vėžio kontrolè prailgina šiu pacientų gyvenimo trukmę [1]. Iprastinis spindulinis gydymas (60-66 Gy dozè), derinamas su chemoterapija, gali užtikrinti lokalią kontrolę 60-70 proc. atvejų [1]. Taikant standartini spindulini gydymą tenka apšvitinti ir nemažą tūrị sveikų audinių, kas gali sąlygoti spindulines komplikacijas ir riboja galimybę saugiai didinti jonizuojančios spinduliuotės dozę. Tiksliau vizualizuojant naviką spindulinio gydymo metu galima siekti mažesnès sveikų audiniu apšvitos bei didesnio jonizuojančiosios spinduliuotės poveikio navikui. Taikant didelių doziu spindulini gydymą labai svarbu ivertinti ir kompensuoti pacientu pozicionavimo paklaidas, kvépavimo sąlygotą organų judẻjimą [2]. Naujos spindulinio gydymo technologijos - moduliuoto intensyvumo spindulinis gydymas (angl. intensity modulated radiotherapy, IMRT), vaizdu valdomas spindulinis gydymas (angl. image guided radiotherapy, IGRT), stereotaksinis kūno spindulinis gydymas (angl. stereotactic body radiotherapy, SBRT) - atveria galimybes navikus apšvitinti labai tiksliai [3-5].

\section{SPINDULINIO GYDYMO PLANAVIMAS}

Būtina sèkmingo plaučiu vèžio spindulinio gydymo sąlyga tikslus naviko ir pažeistų sritinių limfmazgių vizualizavimas ji planuojant. Tai atliekama planavimo kompiuterinèse tomogramose pjūvis po pjūvio identifikuojant apšvitinimo tūrị (angl. clinical target volume, CTV). Kadangi pozitronų emisijos tomografija (PET) itin tiksliai identifi- kuoja pažeistus tarpuplaučio limfmazgius ar naviko apimti atelektuoto plaučio fone, šis tyrimas būtinas planuojant plaučių vèžio spindulini gydymą (1 pav.).

Klinikiniai tyrimai rodo, kad PET duomenu panaudojimas planuojant spindulini gydymą leidžia sumažinti apšvitinamụ audinių tūrí, spindulinių komplikacijų dažnumą bei realizuoti didesnes jonizuojančiosios spinduliuotès dozes [6, 7]. Perspektyviụju tyrimų duomenimis, selektyvus tarpuplaučio limfmazgiu apšvitinimas pagal PET duomenis nepadidina ligos atsinaujinimo limfmazgiuose dažnumo [8, 9]. Tikimasi, kad PET gali padèti identifikuoti navike hipoksiškas, radiorezistentiškas zonas, kurios selektyviai būtų apšvitinamos eskaluotomis dozėmis [10].

Moduliuoto intensyvumo spindulinis gydymas (IMRT) tikriausiai vienas svarbiausiu pastarojo dešimtmečio spindulinio gydymo naujovių. IMRT metodika paremta galimybe moduliuoti jonizuojančios spinduliuotès pluoštą formuojant netaisyklingos formos apšvitinimo tūrius, tiksliai atkartojančius švitinamo taikinio formą išvengiant kritinių organų apšvitos. IMRT panaudojimas plaučiu vėžio spinduliniam gydymui leidžia skirti $20-35$ proc. didesnes dozes [5].

\section{KVĖPAVIMO SĄLYGOTŲ JUDESIŲ VALDYMAS}

Dèl kvẻpavimo juda visi krūtinès ląstos organai, taip pat ir krūtinès ląstoje esantys navikai. Šiu judesių amplitudè ir trajektorija priklauso nuo naviko lokalizacijos, prisitvirtinimo prie gretimų organų. Plaučių navikų judesių amplitudè gali siekti iki $3 \mathrm{~cm}$ kraniokaudaline kryptimi [11]. Paprastai naviko padèties neapibrěžtumas kompensuojamas didinant švitinimo tūrị. Pastaruoju metu į klinikinę 


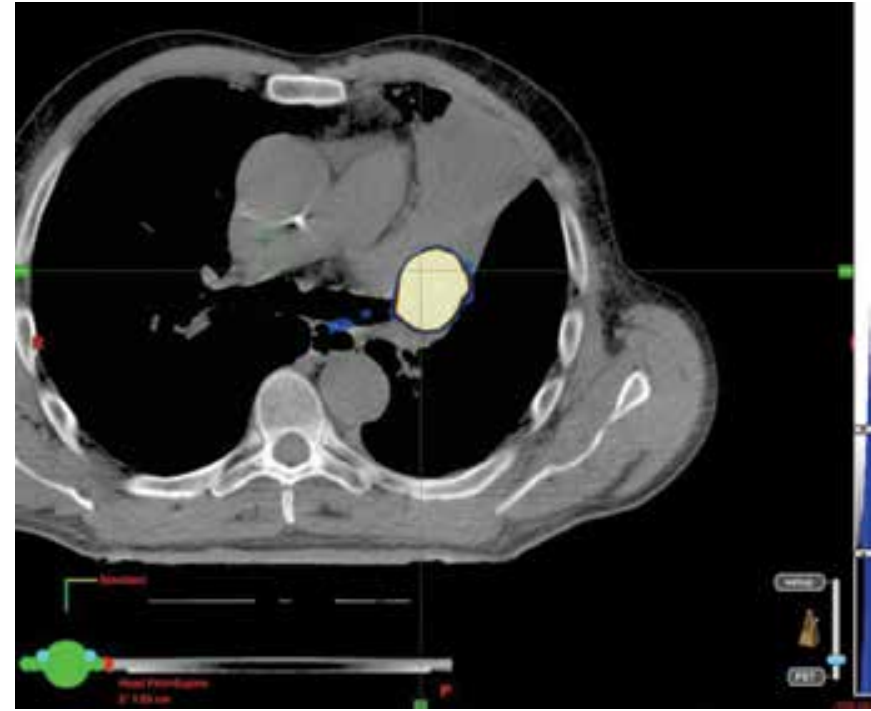

1 pav. PET-KT grindžiamas spindulinio gydymo planavimas: pagal PET duomenis patikslinamos naviko ribos atelektuotame plautyje

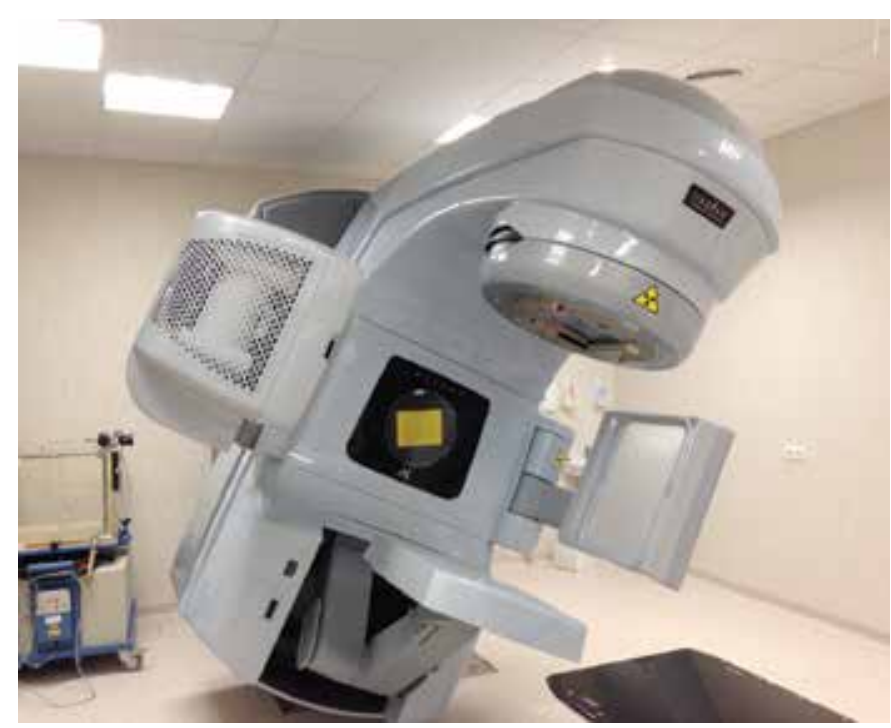

2 pav. Linijinis greitintuvas su kompiuterinès tomografijos priedèliu

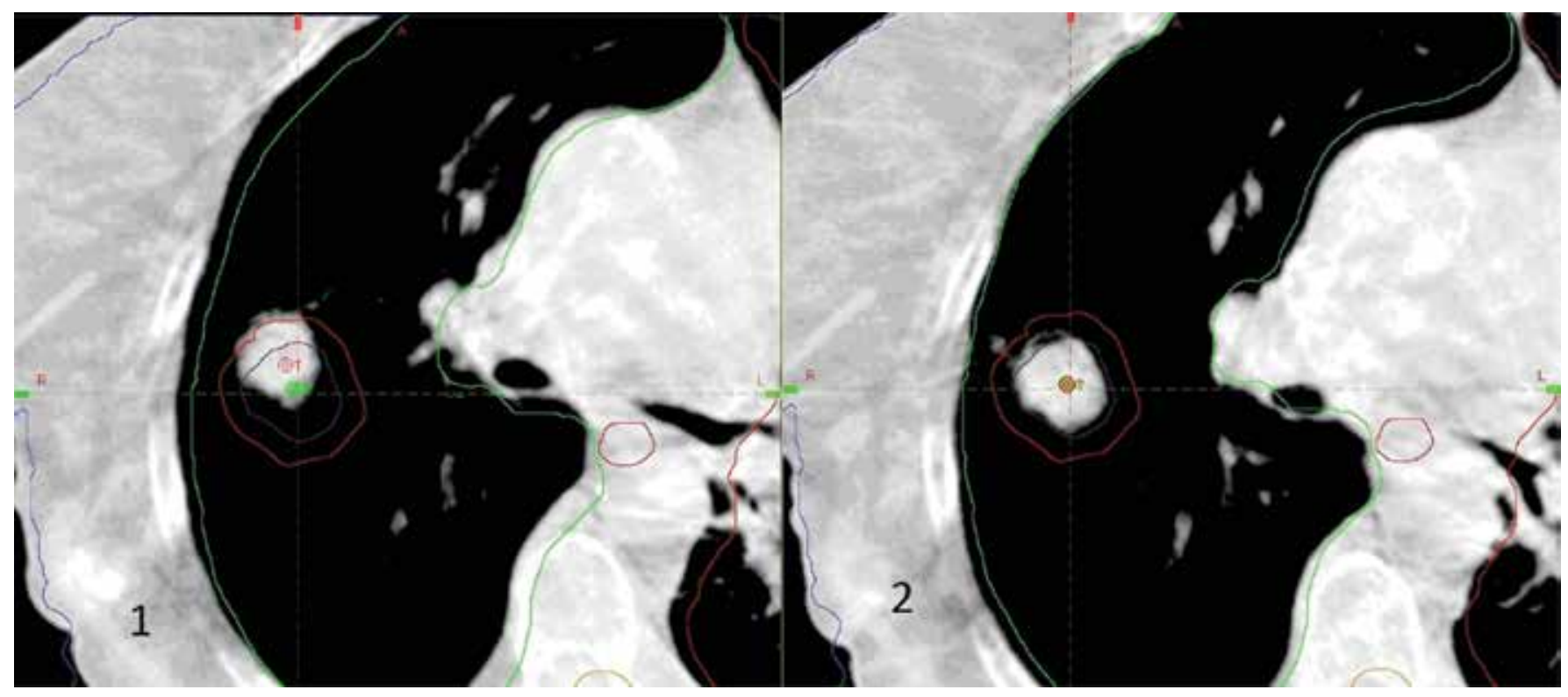

3 pav. Naviko lokalizacija procedūros metu: 1) pradinė; 2) koreguota

praktiką diegiamos aktyvaus kvėpavimo sukeltų judesių valdymo metodikos - užtvarinis spindulinis gydymas (angl. respiratory gated radiotherapy), kvėpavimo sulaikymo (angl. breath hold) ar naviko stebejjimo (angl. tumor tracking) metodikos [11-14]. Taikant užtvarinị spindulini gydymą, navikas yra švitinamas tik tam tikroje kvejpavimo ciklo fazejje. Kvejpavimo ciklas registruojamas panaudojant specialius jutiklius ar implantuojamus rentgenokontrastinius žymeklius $[15,16]$.

\section{VAIZDU VALDOMAS SPINDULINIS GYDYMAS}

Taikant plaučių vėžio spindulinị gydymą stengiamasi sumažinti erdvinès paklaidas, susijusias su paciento pozicio- navimo pokyčiais ar kvėpavimo sukeltais judesiais. Tačiau igyvendinant labai tiksliai suplanuotą spindulini gydymą turi būti sąlygos patikrinti švitinamo taikinio padèti procedūros metu, tai yra taikyti vaizdu valdomą spindulini gydymą. Šiuolaikiniai linijiniai greitintuvai gali turèti kompiuterinès tomografijos priedèlius (2 pav.).

Tai leidžia tiesiogiai procedūros metu vizualizuoti švitinamą taikinị, palyginti jo erdvines koordinates su planavimo metu nustatytomis ir koreguoti galimus nukrypimus [17] (3 pav.).

Kadangi vaizdu valdomas spindulinis gydymas garantuoja labai tikslų švitinamo taikinio lokalizavimą, galima ženkliai mažinti švitinamą tūrị ir optimizuojant jonizuojančiosios spinduliuotès dozę gerinti gydymo rezultatus. 


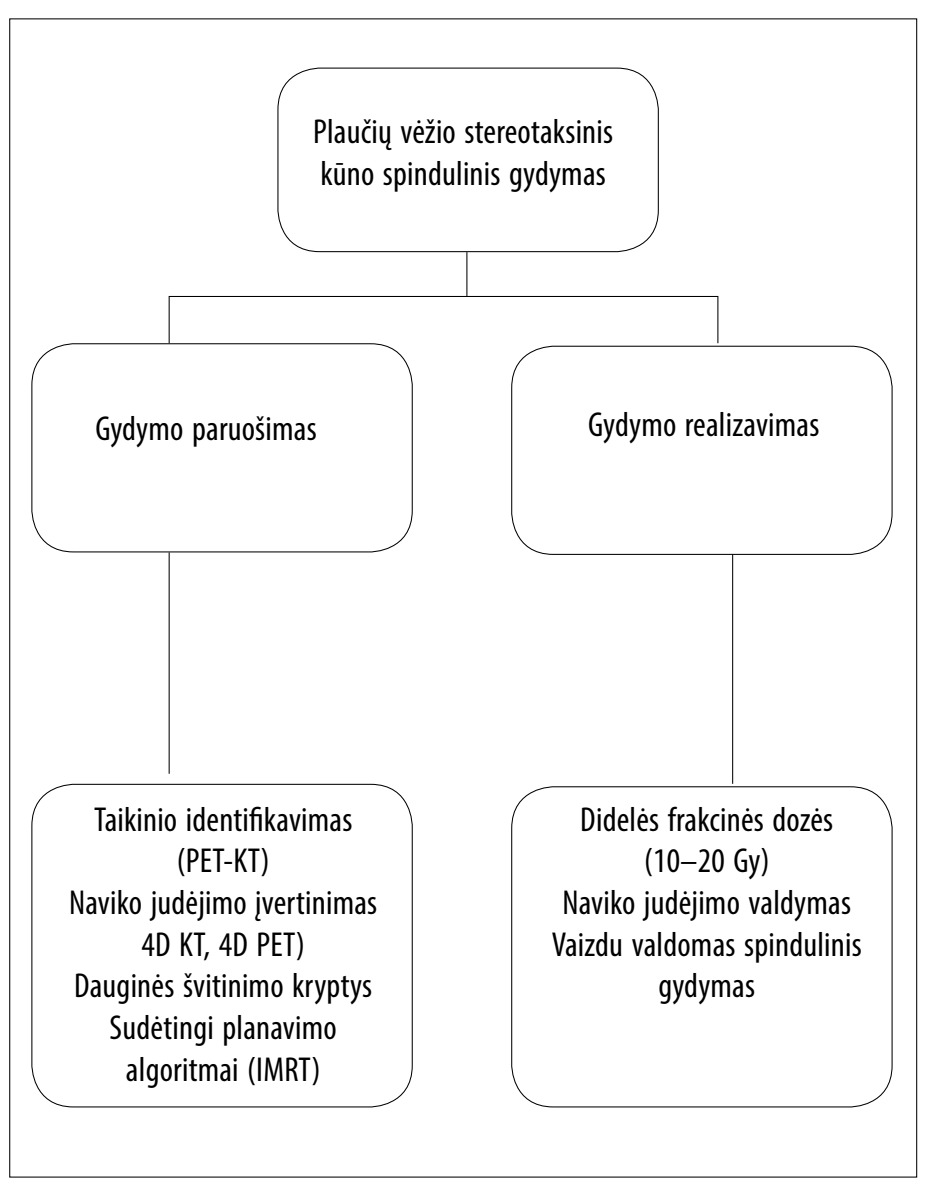

4 pav. Stereotaksinio kūno spindulinio gydymo ypatybès [pagal 18]

\section{Lung cancer radiotherapy possibilities and perspectives}

\section{LAIMONAS JARUŠEVIČIUS, ELONA JUOZAITYTE}

ONCOLOGY INSTITUTE OF LITHUANIAN UNIVERSITY OF HEALTH SCIENCES

Keywords: lung cancer radiotherapy, IMRT, IGRT, SBRT.

Summary. For lung cancer patients the problem of inadequate locoregional control is correlated with a poor survival. Modern radiotherapy allows optimisation of tumor dose, while spearing sorrounding normal tissue. But with standart conformal radiotherapy generally large volumes are treated, what determines risk of treatment related complications and limits possibilities for dose escalation. Higher conformality of the planned dose distributions and higher levels of accuracy in radiotherapy delivery reduces the amount of normal tissues irradiated, such that the tumor and pathologic lymph nodes can be safely irradiated to higher doses. New sophisticated radiotherapy now enables possibility of highly conformal and accurate treatment. In this review we describe recent developments in imaging, treatment planning and treatment delivery that have the potential to increase the efficacy of lung cancer radiation therapy.

\section{LITERATŪRA}

1. Auperin A, Le PC, Rolland E, et al. Meta-analysis of concomitant versus sequential radiochemotherapy in locally advanced non-small-cell lung cancer. J Clin Oncol 2010 May 1;28(13):2181-90.

2. Bhide SA, Nutting CM. Recent advances in radiotherapy. BMC Med 2010;8:25.

3. Chapet O, Fraass BA, Ten Haken RK. Multiple fields may offer better esophagus sparing without increased probability of lung toxicity in optimized IMRT of lung tumors. Int J Radiat Oncol Biol Phys 2006 May 1;65(1):255-65.

\section{STEREOTAKSINIS KÜNO SPINDULINIS GYDYMAS}

Stereotaksinis kūno spindulinis gydymas (SBRT) - naujas spindulinio gydymo metodas, kuriame sinergiškai panaudojamos visos naujosios spindulinio gydymo galimybės. SBRT - tai kelios švitinimo procedūros, kurių metu didelèmis spinduliuotès dozèmis apšvitinami nedideli navikai (4 pav.).

SBRT tapo gera gydymo alternatyva netinkamiems operuoti pacientams, sergantiems ankstyvu stadijų periferiniu plaučių vėžiu. SBRT pranašumai: trumpa gydymo trukmé (1-1,5 savaitès), galimybė gydyti pacientus, sergančius gretutine kardiovaskuline patologija ar esant kvėpavimo funkcijos nepakankamumui [19]. Po ankstyvo periferinio nesmulkiụjų ląstelių plaučių vėžio SBRT 3 metų lokali kontrolè siekia 92-97 proc. [20, 21]. Populiaciniai Olandijos tyrimai rodo, kad platus SBRT iddiegimas i klinikinę praktiką pagerino netinkamų operuoti ankstyvu plaučių vẻžiu sergančių pacientų išgyvenamumą [22].

Naujos technologijos - moduliuoto intensyvumo spindulinis gydymas, vaizdu valdomas spindulinis gydymas, stereotaksinis kūno spindulinis gydymas - tai naujos kartos spindulinis gydymas, atveriantis galimybes navikus apšvitinti labai tiksliai. Nuo 2011 metų šios naujos plaučiu véžio spindulinio gydymo technologijos sẻkmingai taikomos ir Lietuvos sveikatos mokslų universiteto Onkologijos ir hematologijos klinikoje.

4. Grills IS, Yan D, Martinez AA, Vicini FA, Wong JW, Kestin LL. Potential for reduced toxicity and dose escalation in the treatment of inoperable nonsmall-cell lung cancer: a comparison of intensity-modulated radiation therapy (IMRT), 3D conformal radiation, and elective nodal irradiation. Int J Radiat Oncol Biol Phys 2003 Nov 1;57(3):875-90.

5. Schwarz M, Alber M, Lebesque JV, Mijnheer BJ, Damen EM. Dose heterogeneity in the target volume and intensity-modulated radiotherapy to escalate the dose in the treatment of non-small-cell lung cancer. Int J Radiat Oncol Biol Phys 2005 Jun 1;62(2):561-70.

6. Nestle U, Kremp S, Grosu AL. Practical integration of [18F]-FDG-PET and PETCT in the planning of radiotherapy for non-small cell lung cancer (NSCLC): the technical basis, ICRU-target volumes, problems, perspectives. Radiother Oncol 2006 Nov;81(2):209-25.

7. van Der WA, Nijsten $S$, Hochstenbag $M$, et al. Increased therapeutic ratio by 18FDG-PET CT planning in patients with clinical CT stage N2-N3M0 non-small-cell lung cancer: a modeling study. Int J Radiat Oncol Biol Phys 2005 Mar 1;61(3):649-55.

8. Belderbos JS, Heemsbergen WD, De JK, Baas P, Lebesque JV. Final results of a Phase I/II dose escalation trial in non-small-cell lung cancer using three-dimensional conformal radiotherapy. Int J Radiat Oncol Biol Phys 2006 Sep 1:66(1):126-34.

9. De RD, Wanders $\mathrm{S}$, van $\mathrm{HE}$, et al. Selective mediastinal node irradiation based on FDG-PET scan data in patients with non-small-cell lung cancer: a prospective clinical study. Int J Radiat Oncol Biol Phys 2005 Jul 15;62(4):988-94.

10. Aerts HJ, van Baardwijk AA, Petit SF, et al. Identification of residual metabolic active areas within individual NSCLC tumours using a pre-radiotherapy (18) Fluorodeoxyglucose-PET-CT scan. Radiother Oncol 2009 Jun;91(3):386-92.

11. Seppenwoolde $Y$, Shirato $H$, Kitamura K, et al. Precise and real-time measurement of 3D tumor motion in lung due to breathing and heartbeat, measured during radiotherapy. Int J Radiat Oncol Biol Phys 2002 Jul 15:53(4):82234.

12. Adler JR, Jr., Chang SD, Murphy MJ, Doty J, Geis P, Hancock SL. The Cyberknife: a frameless robotic system for radiosurgery. Stereotact Funct Neurosurg 1997;69(1-4 Pt 2):124-8.

13. Keall PJ, Joshi S, Vedam SS, Siebers JV, Kini VR, Mohan R. Four-dimensional radiotherapy planning for DMLC-based respiratory motion tracking. Med Phys 2005 Apr;32(4):942-51.

14. Kubo HD, Hill BC. Respiration gated radiotherapy treatment: a technical study. Phys Med Biol 1996 Jan;41(1):83-91.

15. Haasbeek CJ, Lagerwaard FJ, Cuijpers JP, Slotman BJ, Senan S. Is adaptive treatment planning required for stereotactic radiotherapy of stage I nonsmall-cell lung cancer? Int J Radiat Oncol Biol Phys 2007 Apr 1;67(5):1370-4. 